Przegląd Prawa Konstytucyjnego

- -ISSN 2082-1212--------

DOI 10.15804/ppk.2017.04.13

$-\mathrm{Nr} 4(38) / 2017$

\title{
Sprawozdanie
}

\section{Seminarium naukowe Referendum w sprawie dalszego czlonkostwa Zjednoczonego Królestwa w strukturach Unii Europejskiej, Uniwersytet Jagielloński, Kraków, 27 czerwca 2016 r.}

23 czerwca 2016 r. odbyło się w Zjednoczonym Królestwie Wielkiej Brytanii i Irlandii Północnej referendum w kwestii pozostania w ramach Unii Europejskiej. Problem dalszego uczestnictwa tego państwa w procesie integracji europejskiej stanowił istotny punkt odniesienia w dyskusjach nad ewolucją samej Unii, a także wywoływał liczne kontrowersje na płaszczyźnie wewnętrznej w związku z dalszą formułą państwowości brytyjskiej. Ewentualne reperkusje rezygnacji Zjednoczonego Królestwa z członkostwa w Unii Europejskiej oceniano - tak przed referendum, jak i po jego przeprowadzeniu - w sposób wielowymiarowy, biorąc pod uwagę aspekty polityczne, społeczne i prawne. Doniosłość wskazanego głosowania powszechnego - nota bene dopiero trzeciego ogólnokrajowego referendum, które odbyło się na gruncie brytyjskim została dostrzeżona i skomentowana również przez polskich badaczy zajmujących się szeroko ujmowaną problematyką anglosaską. $Z$ tej bowiem okazji Katedra Konstytucjonalizmu i Ustrojów Państwowych oraz Zakład Teorii Polityki i Państwa Instytutu Nauk Politycznych i Stosunków Międzynarodowych Uniwersytetu Jagiellońskiego podjęły się organizacji poświęconego temu wydarzeniu jednodniowego seminarium.

Otwarcia obrad dokonał dyrektor Instytutu dr hab. Robert Kłosowicz, prof. UJ. Głos zabrali także kierownicy obu jednostek naukowych, które wy- 
szły z inicjatywą organizacji sympozjum - prof. dr hab. Andrzej Zięba oraz dr hab. Piotr Borowiec. W wystąpieniach wskazywano m.in. na wartość, jaką niesie omawianie kwestii referendum w Zjednoczonym Królestwie zarówno z punktu widzenia systemu konstytucyjnego państwa, jak i z uwzględnieniem innych ujęć badawczych, do czego dogodne podstawy tworzy współpraca różnych jednostek naukowych.

Seminarium zostało podzielone na trzy sesje. Pierwsza dotyczyła instytucji referendum z perspektywy konstytucyjnej oraz politycznej, druga obejmowała problematykę stosunku brytyjskich partii politycznych do referendum, natomiast przedmiotem trzeciej było spojrzenie na referendum z perspektywy międzynarodowej.

Sesję pierwszą, którą moderowała dr Małgorzata Kułakowska, otwarło wystąpienie dr hab. Tomasza Wieciecha, które dotyczyło następstw rezygnacji Zjednoczonego Królestwa z członkostwa w Unii Europejskiej z punktu widzenia ustroju państwa. Referent zwracał szczególną uwagę na konsekwencje, jakie może mieć wystąpienie z Unii Europejskiej dla zasady suwerenności parlamentu. Autorem kolejnego wystąpienia był dr hab. Krzysztof Zuba, prof. Uniwersytetu Opolskiego, który poruszył temat rywalizacji międzypartyjnej oraz wewnątrzpartyjnej w związku z referendum z $2016 \mathrm{r}$. W referacie zaakcentowana została kwestia kampanii poprzedzającej wskazane głosowanie oraz strategii przyjmowanych przez najważniejsze brytyjskie partie polityczne. Pierwszą część obrad zamknęło wystąpienie dr Przemysława Biskupa na temat roli referendów $\mathrm{w}$ formowaniu polityki europejskiej oraz dewolucyjnej Zjednoczonego Królestwa. Referent podkreślił rosnące znaczenie - nie tylko w wymiarze politycznym, ale także konstytucyjnym - instytucji referendum w ustroju brytyjskim.

Sesja druga, prowadzona przez dr. hab. Tomasza Wieciecha, rozpoczęła się referatem dr Elżbiety Sadowskiej-Wieciech, którego przedmiotem było zjawisko eurosceptycyzmu w doktrynie Partii Konserwatywnej. Referentka zwróciła uwagę na źródła takiej postawy, analizując stanowisko torysów w dłuższej perspektywie czasowej. Następnie dr Marcin Galent podjął zagadnienie nastawienia brytyjskiej lewicy do członkostwa w Unii Europejskiej, a w szczególności ewolucji, jaką przeszła pod tym względem Partia Pracy. Z kolei dr Tomasz Czapiewski podjął się analizy stanowiska, które w odniesieniu do Brexitu wyrażała Szkocka Partia Narodowa. Koncentrując się na szkoc- 
kim wątku referendum, referent uwzględnił specyfikę tej części Zjednoczonego Królestwa, w tym przede wszystkim znaczenie ujawnianych tendencji niepodległościowych.

Zamykającą seminarium sesję trzecią moderowała dr Elżbieta Sadowska-Wieciech. W jej ramach wygłoszone został dwa referaty. Dr Krzysztof Winkler swoje wystąpienie poświęcił bezpieczeństwu krajowemu oraz międzynarodowemu z perspektywy członkostwa Zjednoczonego Królestwa w Unii Europejskiej. Analiza została przeprowadzona z uwzględnieniem aspektów militarnego i ekonomicznego oraz z punktu widzenia polityki zagranicznej państwa. Dr Małgorzata Kułakowska odniosła się natomiast do sytuacji polskich migrantów w związku z referendum w sprawie Brexitu. Zaakcentowana została kwestia polityki migracyjnej i jej znaczenia z perspektywy głosowania referendalnego z 2016 r.

Seminarium poświęcone referendum w sprawie dalszego członkostwa Zjednoczonego Królestwa w Unii Europejskiej stanowiło dogodną okazję do wymiany poglądów w ramach coraz szerszego środowiska polskich naukowców prowadzących badania nad różnorodnymi aspektami systemu politycznego Zjednoczonego Królestwa. Pozostaje mieć nadzieję, że podobne inicjatywy będą podejmowane także w przyszłości.

Łukasz Jakubiak Uniwersytet Jagielloński w Krakowie 